\title{
ASSESSMENT CRITERIA OF OPTIMAL SOLUTIONS FOR CREATION OF RODS WITH PIECEWISE CONSTANT CROSS-SECTIONS WITH STABILITY CONSTRAINTS OR CONSTRAINTS FOR VALUE OF THE FIRST NATURAL FREQUENCY
} PART 1: THEORETICAL FOUNDATIONS

\author{
Leonid S. Lyakhovich ${ }^{1}$, Pavel A. Akimov ${ }^{1,2,3,4}$, Boris A. Tukhfatullin ${ }^{1}$ \\ ${ }^{1}$ Tomsk State University of Architecture and Building, Tomsk, RUSSIA \\ ${ }^{2}$ Russian Academy of Architecture and Construction Sciences, Moscow, RUSSIA \\ ${ }^{3}$ Scientific Research Center "StaDyO", Moscow, RUSSIA \\ ${ }^{4}$ Peoples' Friendship University of Russia, Moscow, RUSSIA
}

\begin{abstract}
The special properties of optimal systems have been already identified. Besides, criteria has been formulated to assess the proximity of optimal solutions to the minimal material consumption. In particular, the criteria were created for rods with rectangular and I-beam cross-section with stability constraints or constraints for the value of the first natural frequency. These criteria can be used for optimization when the cross sections of a bar change continuously along its length. The resulting optimal solutions can be considered as an idealized object in the sense of the limit. This function of optimal design allows researcher to assess the actual design solution by the criterion of its proximity to the corresponding limit (for example, regarding material consumption). Such optimal project can also be used as a reference point in real design, for example, implementing a step-bystep process of moving away from the ideal object to the real one. At each stage, it is possible to assess the changes in the optimality index of the object in comparison with both the initial and the idealized solution. One of the variants of such a process is replacing the continuous change in the size of the cross sections of the rod along its length with piecewise constant sections. Boundaries of corresponding intervals can be selected based on an ideal feature, and cross-section dimensions can be determined by one of the optimization methods. The distinctive paper is devoted to criteria that allow researcher providing reliable assessment of the endpoint of the optimization process.
\end{abstract}

Keywords: criterion, optimization, special properties, stability, frequency, critical force, buckling, eigenmode, reduced stresses

\section{КРИТЕРИИ ОЦЕНКИ ОПТИМАЛЬНЫХ РЕШЕНИЙ ПРИ ФОРМИРОВАНИИ СТЕРЖНЕЙ С КУСОЧНО- ПОСТОЯННЫМ ИЗМЕНЕНИЕМ ПОПЕРЕЧНЫХ СЕЧЕНИЙ ПРИ ОГРАНИЧЕНИЯХ ПО УСТОЙЧИВОСТИ ИЛИ НА ВЕЛИЧИНУ ПЕРВОЙ СОБСТВЕННОЙ ЧАСТОТЫ ЧАСТЬ 1: ТЕОРЕТИЧЕСКИЕ ОСНОВЫ}

\author{
Л.С. Ляхович ${ }^{1}$, П.А. Акимов ${ }^{1,2,3,4}$, Б.А. Тухфатуллин ${ }^{1}$ \\ ${ }^{1}$ Томский государственный архитектурно-строительный университет, г. Томск, РОССИЯ \\ ${ }^{2}$ Российская академия архитектуры и строительных наук, г. Москва, РОССИЯ \\ ${ }^{3}$ Научно-исследовательский центр СтаДиО, г. Москва, РОССИЯ \\ ${ }^{4}$ Российский университет дружбы народов, г. Москва, РОССИЯ
}

Аннотация: Ранее были выявлены особые свойства оптимальных систем и сформулированы критерии, оценивающие близость оптимальных решений к минимально материалоемкому. В частности, были со- 
Assessment Criteria of Optimal Solutions for Creation of Rods With Piecewise Constant Cross-Sections With Stability Constraints or Constraints for Value of the First Natural Frequency. Part 1: Theoretical Foundations

\begin{abstract}
зданы критерии, для стержней с прямоугольным и двутавровым поперечным сечением при ограничениях по устойчивости или на величину первой частоты собственных колебаний. Эти критерии применимы при оптимизации в случаях, когда поперечные сечения стержня непрерывно изменяются по его длине. Полученные при этом оптимальные решения могут рассматриваться как идеализированный объект в смысле предельного. Данная функция оптимального проекта позволяет оценивать реальное конструкторское решение по критерию его близости к предельному (например, по материалоемкости). Такой оптимальный проект также может использоваться и как ориентир при реальном проектировании, например, реализуя поэтапный процесс отхода от идеального объекта к реальному. При этом на каждом этапе появляется возможность оценки изменения показателя оптимальности объекта по сравнению, как с начальным, так и с идеализированным решением. Одни из вариантов такого процесса состоит в замене непрерывного изменения размеров поперечных сечений стержня по его длине соответствующими кусочно-постоянными участками. Границы участков могут выбираться на основе идеального объекта, а размеры поперечных сечений определяться одним из методов оптимизации. В настоящей статье предлагаются критерии, позволяющие надежно оценивать момент окончания процесса такой оптимизации.
\end{abstract}

Ключевые слова: критерий, оптимизация, особые свойства, устойчивость, частота, критическая сила, формы потери устойчивости, формы собственных колебаний, приведенные напряжения

As is known, there are numerous papers devoted to problem of minimizing the weight of rods under various restrictions. In this connection we should mention pioneer papers of Clausen [1], Lagrange [1], E.L. Nikolai [3], where special properties of optimal constructions were formulated. For example, in paper [4], special criteria were formulated that made it possible to evaluate the proximity of solutions for optimizing rods of rectangular and I-beams to a minimally material-intensive design with limitations on stability or on the value of the first frequency of natural vibrations. The criteria obtained in [4] are applicable for the case when the parameters of the cross sections vary continuously along the length of the rod. Despite the fact that such an optimal project in the overwhelming majority of cases is not directly implemented, it, being the limit, for example, by the minimum material consumption, allows researcher to evaluate the adopted design solution. In addition, the marginal project can be used as the initial stage of the step-by-step process from an ideal object to a technologically acceptable design solution (for example, [4,6]). In particular, such a process may consist of replacing a continuous change in the size of the cross sections of the rod along its length with a corresponding piecewise constant. I order to provide this, sections along the length of the rod are selected, in each of such section the dimensions of the cross-sections do not change. The choice of the boundaries of these sections is determined by technological requirements and objective to approximate to minimally material-intensive solution. After selecting the boundaries of the sections, the dimensions of the cross-sections are determined at each section using one of corresponding optimization methods.

In most optimization methods, the criterion for corresponding the step-by-step process is the state in which at the next search step, the change in the objective function is less than the selected small value in advance.

However, there are cases when, with a small change in the objective function at neighboring steps, the coordinates of the optimum point noticeably change. Obviously, the presence of a criterion that more objectively evaluates the proximity of the solution to the optimum will increase confidence in the result.

Such criteria were formulated in [4] in order to optimize rods of a rectangular and I-shaped cross section under stability restrictions or by the value of the first frequency of natural vibrations, when the parameters of the sections change continuously along the length of the rod. These criteria make it possible to evaluate the proximity of the obtained solution to a minimally demanding project.

The distinctive paper proposes similar criteria for some cases of designing the least weight rods with rectangular or I-shaped piecewise cross-sections continuously varying along the 
length of the rod, with limitations on stability or on the value of the first frequency of natural vibrations.

Let us consider the derivation of such a criterion for a rod with a rectangular cross-section. In this case, it is sufficient to formulate a criterion with a limitation of the magnitude of the first frequency of natural oscillations, but taking into account the influence of the longitudinal force. Such a criterion can also be used when only a stability constraint is introduced. In this case, in the expression of the criterion, the value of the natural frequency is assumed to be zero.

The designations of the dimensions of the cross section are shown in Figure 1.

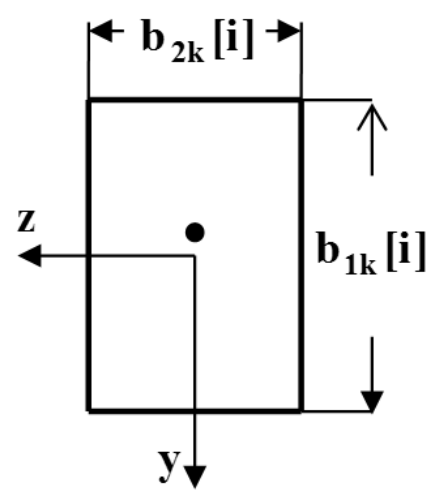

Figure 1. The designations of the dimensions of the cross section.

Rectilinear rods (including multi-span) are considered, bearing mass and loaded with longitudinal force. The rod is divided into sections, within each of which the dimensions of the sections do not change. The designations of the lengths of the sections and the coordinates of their boundaries are shown in Figure 2.

It is required to determine the dimensions of the cross sections of the rod $b_{1 k}[i]$ and $b_{2 k}[i]$ $(i=1,2, . ., n)$, but provided that the first frequencies in the main planes of inertia ( $\omega 1[1]$ and $\omega 2[1])$ are not less than the specified value $\left(\omega_{0}\right)$ and that, with the selected boundaries of the rod sections and the constraints, its volume would be minimal.

Thus, the objective function (the volume of the material of the rod) is defined by formula

$$
V_{0}=\sum_{1}^{n} b_{1 k}[i] * b_{2 k}[i] * l_{u}[i]
$$

Restrictions on the magnitude of the lowest frequency of natural vibrations,

$$
\omega_{0} \leq \omega 1[1], \quad \omega_{0} \leq \omega 2[1]
$$

with allowance for vibrations in the two main planes of inertia of the cross section of the rod, can be written as

$$
\omega_{0}=\omega 1[1]=\omega 2[1]
$$

It is known that if $\omega 1[1]$ and $\omega 2[1]$ are the first frequencies of natural vibrations in the principal planes of inertia, then the energy functionals must continuously take zero values when the cross sections are continuously changed. Thus, we have

$$
\begin{aligned}
\ni_{\omega 1}= & \frac{1}{2} \int_{0}^{l}\left\{E I_{1}(x) *\left(v_{\omega}^{\prime \prime}\right)^{2}-P(x) *\left(v_{\omega}^{\prime}\right)^{2}-\right. \\
& \left.-\omega^{2} *\left[m(x)+\rho^{*} F(x)\right]^{*} v_{\omega}^{2}\right\} d x=0 ; \\
\ni_{\omega 2}= & \frac{1}{2} \int_{0}^{l}\left\{E I_{2}(x) *\left(w_{\omega}^{\prime \prime}\right)^{2}-P(x) *\left(w_{\omega}^{\prime}\right)^{2}-\right. \\
& \left.-\omega^{2} *\left[m(x)+\rho^{*} F(x)\right]^{*} w_{\omega}^{2}\right\} d x=0 .
\end{aligned}
$$

With a piecewise constant change in cross sections, requirements (3) and (4) with allowance for restrictions (2), take the form

$$
\begin{aligned}
\ni_{\omega 1}= & \frac{1}{2} \sum_{i=1}^{n} \int_{x[i-1]}^{x[i]}\left\{E I_{1}[i]^{*}\left(v_{\omega}^{\prime \prime}\right)^{2}-P[i]^{*}\left(v_{\omega}^{\prime}\right)^{2}-\right. \\
& -(\omega 1[1])^{2} *\left[m(x)+\rho^{*} F[i]^{*} v_{\omega}^{2}\right\} d x=0 ; \\
\ni_{\omega 2}= & \frac{1}{2} \sum_{i=1}^{n} \int_{x[i-1]}^{x[i]}\left\{E I_{2}[i]^{*}\left(w_{\omega}^{\prime \prime}\right)^{2}-P[i]^{*}\left(w_{\omega}^{\prime}\right)^{2}-\right. \\
& -(\omega 2[1])^{2} *\left[m(x)+\rho^{*} F[i]^{*} w_{\omega}^{2}\right\} d x=0 .
\end{aligned}
$$

Here $E$ is the elastic modulus of the material of the rod; $I_{1}(x), I_{1}[i], I_{2}(x), I_{2}[i]$ are respectively, 
Assessment Criteria of Optimal Solutions for Creation of Rods With Piecewise Constant Cross-Sections With Stability Constraints or Constraints for Value of the First Natural Frequency. Part 1: Theoretical Foundations

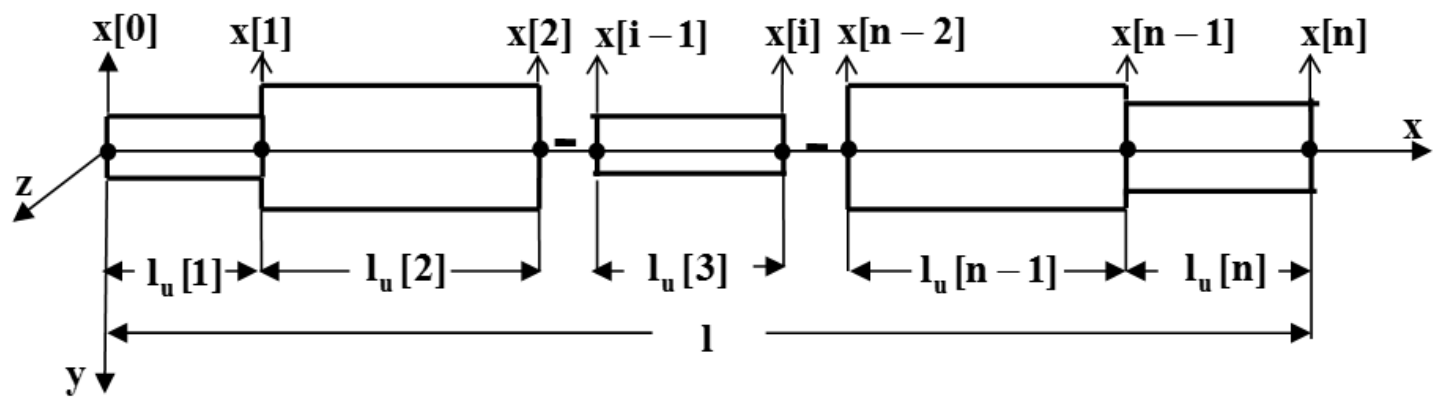

Figure 2. The designations of the lengths of the sections and the coordinates of their boundaries.

the moments of inertia of the cross sections of the rod in the main planes of inertia; $v_{\omega}, w_{\omega}$ are the coordinates of the modes of natural vibrations in the main planes of inertia; $\rho$ is the specific gravity of the material of the rod;

$$
F(x)=b_{1}(x) * b_{2}(x), \quad F[i]=b_{1 k}[i] * b_{2 k}[i]
$$

is the cross-sectional area of the rod.

Thus, it is required to find the values $b_{1 k}[i]$ and $b_{2 k}[i]$ that give the function (1) the minimum value when conditions (5), (6) are satisfied.

So, we have to consider corresponding parametric problem.

The expression extremum of which will ensure the minimum of function (1) and the fulfillment of conditions (5), (6), can be written as

$$
\begin{aligned}
& V_{0 \omega}=\sum_{i=1}^{n} b_{1 k}[i]^{*} b_{2 k}[i]^{*} l_{u}[i]- \\
& -\sum_{i=1}^{n} \int_{x[i-1]}^{x[i]}\left\{\lambda _ { \omega 1 } * \left[E * \frac{b_{1 k}^{3}[i] * b_{2 k}[i]}{12} *\left(v_{\omega}^{\prime \prime}\right)^{2}-\right.\right. \\
& -P[i] *\left(v_{\omega}^{\prime}\right)^{2}- \\
& \left.-(\omega 1[1])^{2} *\left(m(x)+\rho^{*} b_{1 k}[i]^{*} b_{2 k}[i]\right)^{*} v_{\omega}^{2}\right]- \\
& -\lambda_{\omega 2} *\left[E^{*} \frac{b_{1 k}[i] * b_{2 k}^{3}[i]}{12} *\left(w_{\omega}^{\prime \prime}\right)^{2}-\right. \\
& -P(i)^{*}\left(w_{\omega}^{\prime}\right)^{2}- \\
& \left.\left.-(\omega 2[1])^{2} *\left(m(x)+\rho^{*} b_{1 k}[i] * b_{2 k}[i]\right) w_{\omega}^{2}\right]\right\} d x,
\end{aligned}
$$

where $\lambda_{\omega 1}$ and $\lambda_{\omega 2}$ are arbitrary factors. In the parametric problem, the factors $\lambda_{\omega 1}$ and $\lambda_{\omega 2}$ are constant values.
Obviously, variations of expression (7) with respect to $\lambda_{\omega 1}$ and $\lambda_{\omega 2}$ lead to the fulfillment of conditions (5) and (6), and therefore to constraint (2).

In order to find the minimum of expression (7) under conditions (5), (6) it is necessary to write the system of equations

$$
\frac{\partial V_{0 \omega}}{\partial b_{1 k}[i]}=0 ; \quad \frac{\partial V_{0 \omega}}{\partial b_{2 k}[i]}=0, \ldots \quad(i=1,2, . ., n) .
$$

Let us write $i$-th couple of equations

$$
\begin{aligned}
& \frac{\partial V_{0 \omega}}{\partial b_{1 k}[i]}=b_{2 k}[i] * l_{u}[i]- \\
& -\int_{x[i-1]}^{x[i]} \lambda_{\omega 1} *\left[E * \frac{b_{1 k}^{2}[i] * b_{2 k}[i]}{4} *\left(v_{\omega}^{\prime \prime}\right)^{2}-\right. \\
& -\left\{(\omega 1[1])^{2} * \rho^{*} b_{2 k}[i] * v_{\omega}^{2}\right]- \\
& -\lambda_{\omega 2} *\left[E * \frac{b_{2 k}^{3}[i]}{12} *\left(w_{\omega}^{\prime \prime}\right)^{2}-\right. \\
& \left.\left.-(\omega 2[1])^{2} * \rho^{*} b_{2 k}[i] * w_{\omega}^{2}\right]\right\} d x=0 \\
& \frac{\partial V_{0 \omega}}{\partial b_{2 k}[i]}=b_{1 k}[i] * l_{u}[i]- \\
& -\int_{x[i-1]}^{x[i]}\left\{\lambda _ { \omega 1 } * \left[E^{*} \frac{b_{1 k}^{3}[i]}{12} *\left(v_{\omega}^{\prime \prime}\right)^{2}-\right.\right. \\
& \left.-(\omega 1[1])^{2} * \rho^{*} b_{1 k}[i] * v_{\omega}^{2}\right]- \\
& -\lambda_{\omega 2} *\left[E * \frac{b_{1 k}[i] * b_{2 k}^{2}[i]}{4} *\left(w_{\omega}^{\prime \prime}\right)^{2}-\right. \\
& \left.-(\omega 2[1])^{2} * \rho * b_{1 k}[i] * w_{\omega}^{2}\right\} d x=0 .
\end{aligned}
$$


Dividing all the terms of the first equation by $b_{2 k}[i]$, and the second by $b_{1 k}[i]$ and performing simple transformations, we get

$$
\begin{aligned}
& \int_{x[i-1]}^{x[i]}\left\{\lambda _ { \omega 1 } * \left[E * \frac{b_{1 k}^{2}[i]}{4} *\left(v_{\omega}^{\prime \prime}\right)^{2}-\right.\right. \\
& \left.-(\omega 1[1])^{2} * \rho^{*} v_{\omega}^{2}\right]+\lambda_{\omega 2} *\left[E * \frac{b_{2 k}^{2}[i]}{12} *\left(w_{\omega}^{\prime \prime}\right)^{2}-\right. \\
& \left.\left.-(\omega 2[1])^{2} * \rho^{*} w_{\omega}^{2}\right]\right\} d x=l_{u}[i] ; \\
& \int_{x[i-1]}^{x[i]}\left\{\lambda _ { \omega 1 } * \left[E * \frac{b_{1 k}^{2}[i]}{12} *\left(v_{\omega}^{\prime \prime}\right)^{2}-\right.\right. \\
& \left.-(\omega 1[1])^{2} * \rho^{*} v_{\omega}^{2}\right]+\lambda_{\omega 2} *\left[E * \frac{b_{2 k}^{2}[i]}{4} *\left(w_{\omega}^{\prime \prime}\right)^{2}-\right. \\
& \left.\left.-(\omega 2[1])^{2} * \rho^{*} w_{\omega}^{2}\right]\right\} d x=l_{u}[i] .
\end{aligned}
$$

Multiplying all terms of the obtained equations by $E$ and taking into account that

$$
\begin{aligned}
\sigma_{1}(x)=\frac{E}{2} * b_{1}(x) & *\left(v_{\omega}^{\prime \prime}\right) \\
\sigma_{2}(x) & =\frac{E}{2} * b_{2}(x) *\left(w_{\omega}^{\prime \prime}\right)
\end{aligned}
$$

we can rewrite corresponding equations:

$$
\begin{aligned}
& \int_{x[i-1]}^{x[i]}\left\{\lambda_{\omega 1} *\left[\sigma_{1 \omega}^{2}(x)-(\omega 1[1])^{2} * E * \rho^{*} v_{\omega}^{2}\right]+\right. \\
& \quad+\lambda_{\omega 2} *\left[\frac{1}{3} * \sigma_{2 \omega}^{2}(x)-\right. \\
& \left.\left.\quad-(\omega 2[1])^{2} * E^{*} \rho * w_{\omega}^{2}\right]\right\} d x=l_{u}[i] * E ; \\
& \int_{x[i-1]}^{x[i]}\left\{\lambda_{\omega 1} *\left[\frac{]}{3} * \sigma_{1 \omega}^{2}(x)-(\omega 1[1])^{2} * E^{*} \rho^{*} v_{\omega}^{2}\right]+\right. \\
& \quad+\lambda_{\omega 2} *\left[\sigma_{2 \omega}^{2}(x)-\right. \\
& \left.\left.\quad-(\omega 2[1])^{2} * E^{*} \rho^{*} w_{\omega}^{2}\right]\right\} d x=l_{u}[i] * E,
\end{aligned}
$$

where $\sigma_{1 \omega}(x)$ and $\sigma_{2 \omega}(x)$ are normal stresses in the extreme fibers of the rod from bending moments arising from natural vibrations in the main planes of inertia. These stresses, as well as displacements, are determined up to a constant factor.

Taking the difference of equations (9), we obtain

$$
\begin{aligned}
\frac{2}{3} * \lambda_{\omega 1} * \int_{x[i-1]}^{x[i]} \sigma_{1 \omega}^{2}(x) d x- & \\
& -\frac{2}{3} * \lambda_{\omega 2} * \int_{x[i-1]}^{x[i]} \sigma_{2 \omega}^{2}(x) d x=0 .
\end{aligned}
$$

Therefor the following formulas can be obtained:

$$
\begin{gathered}
\lambda_{\omega 1} * \int_{x[i-1]}^{x[i]} \sigma_{1 \omega}^{2}(x) d x=\lambda_{\omega 2} * \int_{x[i-1]}^{x[i]} \sigma_{2 \omega}^{2}(x) d x ; \\
\lambda_{\omega 1}=\lambda_{\omega 2} * \frac{\int_{x[i-1]}^{x[i]} \sigma_{2 \omega}^{2} d x}{\int_{x[i]}^{x[i-1]} \sigma_{1 \omega}^{2} d x} ; \\
\lambda_{\omega 2}=\lambda_{\omega 1} * \frac{\int_{x[i-1]}^{x[i]} \sigma_{1 \omega}^{2} d x}{\int_{x[i]}^{x[i-1]} \sigma_{2 \omega}^{2} d x}
\end{gathered}
$$

Based on (13)-(15), equations (11) can be written in the following form

$$
\begin{aligned}
& \int_{x[i-1]}^{x[i]}\left\{\lambda_{\omega 1} *\left[\sigma_{1 \omega}^{2}(x) d x-(\omega 1[1])^{2} * E * \rho^{*} v_{\omega}^{2}\right]+\right. \\
& \quad+\lambda_{\omega 2} * \frac{1}{3} * \sigma_{2 \omega}^{2}(x)- \\
& \left.\quad-\lambda_{\omega 2}(\omega 2[1])^{2} * E * \rho^{*} w_{\omega}^{2}\right\} d x=l_{u}[i] * E \\
& \int_{x[i-1]}^{x[i]}\left\{\lambda_{\omega 1} *\left[\frac{]}{3} * \sigma_{1 \omega}^{2}(x)-(\omega 1[1])^{2} * E^{*} \rho^{*} v_{\omega}^{2}\right]+\right. \\
& \quad+\lambda_{\omega 2} * \sigma_{2 \omega}^{2}(x)- \\
& \left.\quad-\lambda_{\omega 2} *(\omega 2[1])^{2} * E^{*} \rho^{*} w_{\omega}^{2}\right\} d x=l_{u}[i] * E
\end{aligned}
$$


Assessment Criteria of Optimal Solutions for Creation of Rods With Piecewise Constant Cross-Sections With Stability Constraints or Constraints for Value of the First Natural Frequency. Part 1: Theoretical Foundations

$$
\begin{aligned}
& \lambda_{\omega 1} \int_{x[i-1]}^{x[i]}\left[\sigma_{1 \omega}^{2}(x) d x-(\omega 1[1])^{2} * E^{*} \rho * v_{\omega}^{2}\right] d x+ \\
& +\frac{1}{3} * \lambda_{\omega 1} * \frac{\int_{x[i-1]}^{x[i]} \sigma_{1 \omega}^{2} d x}{\int_{x[i-1]}^{x[i]} \sigma_{2 \omega}^{2} d x} * \int_{x[i-1]}^{x[i]} \sigma_{2 \omega}^{2}(x) d x-
\end{aligned}
$$

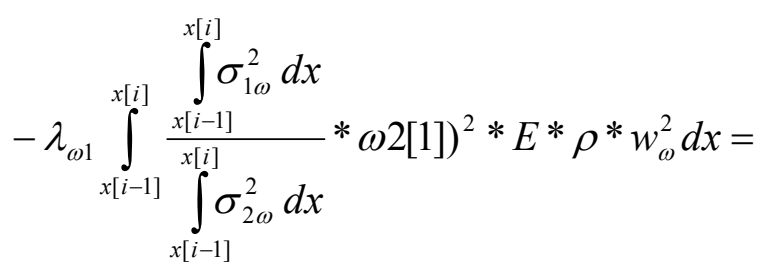

$$
\begin{aligned}
& =l_{u}[i] * E \\
& \frac{1}{3} * \lambda_{\omega 2} * \frac{\int_{x[i-1]}^{x[i]} \sigma_{2 \omega}^{2} d x}{\int_{x[i-1]}^{x[i]} \sigma_{1 \omega}^{2} d x} \int_{x[i]}^{x[i-1]} \sigma_{1 \omega}^{2}(x) d x- \\
& \left.-\int_{x[i-1]}^{x[i]} \lambda_{\omega 1} *(\omega 1[1])^{2} * E^{*} \rho * v_{\omega}^{2}\right] d x+ \\
& \frac{1}{l_{u}[i]} * \int_{x[i-1]}^{x[i]}\left\{\frac{4}{3} * \sigma_{1 \omega}^{2}(x)-(\omega 1[1])^{2} * E * \rho^{*} v_{\omega}^{2}-\right. \\
& \int_{1 \omega}^{x[i]} \sigma_{1 \omega}^{2} d x \\
& \left.-\frac{x[i-1]}{x[i]} *(\omega 2[1])^{2} * E^{*} \rho * w_{\omega}^{2}\right\} d x= \\
& \int_{x[i-1]}^{2} \sigma_{2 \omega}^{2} d x \\
& =E=\text { Const } \text {; } \\
& \frac{1}{l_{u}[i]} * \int_{x[i-1]}^{x[i]}\left\{\frac{4}{3} * \sigma_{2 \omega}^{2}(x)-\frac{\int_{x[i-1]}^{x[i]} \sigma_{2 \omega}^{2} d x}{\int_{x[i-1]}^{x[i]} \sigma_{1 \omega}^{2} d x} *\right. \\
& \left.*(\omega 1[1])^{2} * E * \rho * v_{\omega}^{2}\right]- \\
& \left.-(\omega 2[1])^{2} * E^{*} \rho^{*} w_{\omega}^{2}\right\} d x=E=\text { Const. }
\end{aligned}
$$$$
+\lambda_{\omega 2} * \int_{x[i-1]}^{x[i]}\left[\sigma_{2 \omega}^{2}(x)-(\omega 2[1])^{2} * E * \rho * w_{\omega}^{2}\right] d x=
$$$$
=l_{u}[i] * E
$$$$
\lambda_{\omega 1} * \int_{x[i-1]}^{x[i]}\left\{\frac{4}{3} * \sigma_{1 \omega}^{2}(x)-(\omega 1[1])^{2} * E * \rho * v_{\omega}^{2}-\right.
$$$$
\int^{x[i]} \sigma_{1 \omega}^{2} d x
$$$$
\left.-\frac{x[i-1]}{x[i]} *(\omega 2[1])^{2} * E * \rho * w_{\omega}^{2}\right\} d x=
$$$$
\int_{x[i-1]}^{2} \sigma_{2 \omega}^{2} d x
$$$$
=l_{u}[i] * E
$$

$$
\begin{aligned}
& \lambda_{\omega 2} * \int_{x[i-1]}^{x[i]}\left\{\frac{4}{3} * \sigma_{2 \omega}^{2}(x)-\frac{\int_{x[i-1]}^{x[i]} \sigma_{2 \omega}^{2} d x}{\int_{x[i]}^{x[-1]} \sigma_{1 \omega}^{2} d x} *\right. \\
& \left.*(\omega 1[1])^{2} * E^{*} \rho * v_{\omega}^{2}\right]- \\
& \left.-(\omega 2[1])^{2} * E^{*} \rho^{*} w_{\omega}^{2}\right\} d x=l_{u}[i] * E .
\end{aligned}
$$

Substituting $\omega_{0}=\omega 1[1]=\omega 2[1]$ and dividing by $4 / 3$, we obtain

$$
\frac{1}{l_{u}[i]} * \int_{x[i-1]}^{x[i]}\left[\sigma_{1 \omega}^{2}(x)-\frac{3}{4} *\left(\omega_{0}\right)^{2} * E^{*} \rho *\left(v_{\omega}^{2}+\right.\right.
$$

$$
\left.\left.+\frac{\int_{x[i-1]}^{x[i]} \sigma_{1 \omega}^{2} d x}{\int_{x[i-1]}^{x[i]} \sigma_{2 \omega}^{2} d x} * w_{\omega}^{2}\right)\right] d x=\text { Const }
$$

$$
\begin{aligned}
& \frac{1}{l_{u}[i]} * \int_{x[i-1]}^{x[i]}\left[\sigma_{2 \omega}^{2}(x)-\frac{3}{4} *\left(\omega_{0}\right)^{2} * E * \rho *\right. \\
& \left.*\left(\frac{\int_{x[i-1]}^{x[i]} \sigma_{2 \omega}^{2} d x}{\int_{x[i-1]}^{x[i]} \sigma_{1 \omega}^{2} d x} * v_{\omega}^{2}+w_{\omega}^{2}\right)\right] d x=\text { Const. }
\end{aligned}
$$

If the boundary conditions in the principal planes of inertia are the same, then 


$$
v_{\omega}=w_{\omega} ; \quad \sigma_{1 \omega}=\sigma_{2 \omega}
$$

and (20) take the form

$$
\begin{aligned}
& \frac{1}{l_{u}[i]} * \int_{x[i-1]}^{x[i]}\left[\sigma_{1 \omega}^{2}(x)-1.5 *\left(\omega_{0}\right)^{2} * E^{*} \rho^{*} v_{\omega}^{2}\right] d x= \\
& \quad=\text { Const; } \\
& \frac{1}{l_{u}[i]} * \int_{x[i-1]}^{x[i]}\left[\sigma_{2 \omega}^{2}(x)-1.5 *\left(\omega_{0}\right)^{2} * E * \rho * w_{\omega}^{2}\right] d x= \\
& \quad=\text { Const. }
\end{aligned}
$$

Let us introduce the notation

$$
\begin{gathered}
S_{1}[i]=\frac{1}{l_{u}[i]} * \int_{x[i-1]}^{x[i]}\left[\sigma_{1 \omega}^{2}(x)-\frac{3}{4} *\left(\omega_{0}\right)^{2} * E^{*} \rho^{*}\right. \\
\left.*\left(v_{\omega}^{2}+\int_{x[i-1]}^{x[i]} \sigma_{1 \omega}^{2} d x *\left(\int_{x[i-1]}^{x[i]} \sigma_{2 \omega}^{2} d x\right)^{-1} * w_{\omega}^{2}\right)\right] d x ; \\
S_{2}[i]=\frac{1}{l_{u}[i]} * \int_{x[i-1]}^{x[i]}\left[\sigma_{2 \omega}^{2}(x)-\frac{3}{4} *\left(\omega_{0}\right)^{2} * E * \rho^{*}\right. \\
\left.*\left(\int_{x[i-1]}^{x[i]} \sigma_{1 \omega}^{2} d x *\left(\int_{x[i-1]}^{x[i]} \sigma_{2 \omega}^{2} d x\right)^{-1} * v_{\omega}^{2}+w_{\omega}^{2}\right)\right] d x .
\end{gathered}
$$

Thus, we can rewrite (20) and (21) in the following form

$$
\begin{aligned}
& S_{1}[i]=\frac{1}{l_{u}[i]} * \int_{x[i-1]}^{x[i]}\left[\sigma_{1 \omega}^{2}(x)-\frac{3}{4} *\left(\omega_{0}\right)^{2} * E^{*} \rho^{*}\right. \\
& \left.*\left(v_{\omega}^{2}+\int_{x[i-1]}^{x[i]} \sigma_{1 \omega}^{2} d x *\left(\int_{x[i-1]}^{x[i]} \sigma_{2 \omega}^{2} d x\right)^{-1} * w_{\omega}^{2}\right)\right] d x= \\
& =\text { const } \\
& S_{2}[i]=\frac{1}{l_{u}[i]} * \int_{x[i-1]}^{x[i]}\left[\sigma_{2 \omega}^{2}(x)-\frac{3}{4} *\left(\omega_{0}\right)^{2} * E^{*} \rho^{*}\right. \\
& \left.\quad *\left(\int_{x[i-1]}^{x[i]} \sigma_{1 \omega}^{2} d x *\left(\int_{x[i-1]}^{x[i]} \sigma_{2 \omega}^{2} d x\right)^{-1} * v_{\omega}^{2}+w_{\omega}^{2}\right)\right] d x= \\
& =\text { const; }
\end{aligned}
$$

$$
\begin{aligned}
& S_{1}[i]=\frac{1}{l_{u}[i]} * \\
& * \int_{x[i-1]}^{x[i]}\left[\sigma_{1 \omega}^{2}(x)-\frac{3}{2} *\left(\omega_{0}\right)^{2} * E^{*} \rho^{*} v_{\omega}^{2}\right] d x= \\
& \quad=\text { const; } \\
& S_{2}[i]=\frac{1}{l_{u}[i]} * \\
& * \int_{x[i-1]}^{x[i]}\left[\sigma_{2 \omega}^{2}(x)-\frac{3}{2} *\left(\omega_{0}\right)^{2} * E^{*} \rho^{*} w_{\omega}^{2}\right] d x= \\
& \quad=\text { const. }
\end{aligned}
$$

Both equations (21) become identical. Nevertheless, the conservation of two equations is advisable in order to construct algorithms for the implementation of criterion (16).

If the natural vibrations are considered only in one of the main planes of inertia, then, based on (11), the criteria are presented in the form

$$
\begin{aligned}
& S_{1}[i]=\frac{1}{l_{u}[i]} * \\
& \quad * \int_{x[i-1]}^{x[i]}\left[\sigma_{1 \omega}^{2}(x)-\left(\omega_{0}\right)^{2} * E^{*} \rho * v_{\omega}^{2}\right] d x=\text { const } \\
& S_{2}[i]=\frac{1}{l_{u}[i]} * \\
& \quad * \int_{x[i-1]}^{x[i]}\left[\sigma_{2 \omega}^{2}(x)-\left(\omega_{0}\right)^{2} * E^{*} \rho^{*} w_{\omega}^{2}\right] d x=\text { const. }
\end{aligned}
$$

It is advisable to normalize values of $S_{1}[i]$ and $S_{2}[i]$. One of the normalization options, for instance for $S_{1}[i](i=1,2, \ldots, n)$ includes choosing the highest value in this series and dividing all members of the series into it. Thus, in a row there will be no values of larger than unity. The proximity of the solution to the optimum will be evaluated by the proximity of the values to unity. The series is also normalized.

Let us compare the criteria (23), (24), (25) obtained with a piecewise constant change in rectangular cross sections with similar criteria with 
a continuous change. These criteria were obtained in [6] and have the form

$$
\begin{aligned}
& \sigma_{1 \omega}^{2}(x)-\frac{3}{4} * E * \rho^{*}\left(\omega_{0} * k_{\omega}\right)^{2} * \\
& *\left(v_{\omega}^{2}+\frac{\sigma_{1 \omega}^{2}}{\sigma_{2 \omega}^{2}} * w_{\omega}^{2}\right)=\mathrm{const} \\
& \sigma_{2 \omega}^{2}(x)-\frac{3}{4} * E * \rho^{*}\left(\omega_{0} * k_{\omega}\right)^{2} * \\
& *\left(\frac{\sigma_{2 \omega}^{2}}{\sigma_{1 \omega}^{2}} * v_{\omega}^{2}+w_{\omega}^{2}\right)=\mathrm{const} ;
\end{aligned}
$$

or

$$
\begin{aligned}
& \bar{\sigma}_{1 \omega}= \\
& =\sqrt{\sigma_{1 \omega}^{2}(x)-\frac{3}{4} * E^{*} \rho^{*}\left(\omega_{0} * k_{\omega}\right)^{2} *\left(v_{\omega}^{2}+\frac{\sigma_{1 \omega}^{2}}{\sigma_{2 \omega}^{2}} w_{\omega}^{2}\right)}= \\
& =\text { const } \\
& \bar{\sigma}_{2 \omega}= \\
& =\sqrt{\sigma_{2 \omega}^{2}(x)-\frac{3}{4} * E^{*} \rho^{*}\left(\omega_{0} * k_{\omega}\right)^{2} *\left(\frac{\sigma_{2 \omega}^{2}}{\sigma_{1 \omega}^{2}} v_{\omega}^{2}+w_{\omega}^{2}\right)}= \\
& =\text { const }
\end{aligned}
$$$$
\sigma_{1 \omega}^{2}(x)-\frac{3}{2} *\left(\omega_{0} * k_{\omega}\right)^{2} * E^{*} \rho * v_{\omega}^{2}=\text { const }
$$$$
\sigma_{2 \omega}^{2}(x)-\frac{3}{2} *\left(\omega_{0} * k_{\omega}\right)^{2} * E^{*} \rho * w_{\omega}^{2}=\text { const }
$$

or

$$
\begin{aligned}
& \bar{\sigma}_{1 \omega}=\sqrt{\sigma_{1 \omega}^{2}(x)-\frac{3}{2} *\left(\omega_{0} * k_{\omega}\right)^{2} * E^{*} \rho * v_{\omega}^{2}}= \\
& =\text { const } \\
& \bar{\sigma}_{2 \omega}=\sqrt{\sigma_{2 \omega}^{2}(x)-\frac{3}{2} *\left(\omega_{0} * k_{\omega}\right)^{2} * E^{*} \rho^{*} w_{\omega}^{2}}= \\
& =\text { const } \\
& \sigma_{1 \omega}^{2}(x)-\left(\omega_{0} * k_{\omega}\right)^{2} * E^{*} \rho^{*} v_{\omega}^{2}=\text { const } \\
& \sigma_{2 \omega}^{2}(x)-\left(\omega_{0} * k_{\omega}\right)^{2} * E^{*} \rho^{*} w_{\omega}^{2}=\text { const }
\end{aligned}
$$

$$
\begin{aligned}
& \bar{\sigma}_{1 \omega}=\sqrt{\sigma_{1 \omega}^{2}(x)-\left(\omega_{0} * k_{\omega}\right)^{2} * E^{*} \rho^{*} v_{\omega}^{2}}= \\
& \quad=\text { const } \\
& \bar{\sigma}_{2 \omega}=\sqrt{\sigma_{2 \omega}^{2}(x)-\left(\omega_{0} * k_{\omega}\right)^{2} * E^{*} \rho^{*} w_{\omega}^{2}}= \\
& \quad=\text { const } ;
\end{aligned}
$$

Each of the criteria is presented in two versions. The second versions of presenting the criteria are optional. They were presented only in order to emphasize their connection with the previously formulated criteria (for example, in [3]), where the constant stresses served as a sign of optimality under stability limitations, in the extreme fibers of the rod from bending moments arising from loss of stability.

The use of the second versions of the criteria with restrictions on the value of the lowest frequency of natural oscillations to evaluate the optimization process at the initial stages of the search can lead to negative values of the radical expressions. Therefore, the first criteria presentation options should be used in order to avoid malfunctions in the computing process.

As noted above, the formulated criteria can be used when only a stability constraint is introduced. In this case, in the criteria expressions, the value of the natural frequency is assumed to be zero.

A comparison of the criteria (23), (24), (25) obtained with a piecewise constant change in rectangular cross sections with similar criteria for a corresponding continuous change (26), (28) and (30) shows that under the integrals in (24) and (25) are expressions (28) and (30), respectively, and in (23) the modified expression (26). Criteria $S_{1}[i]$ and $S_{2}[i]$ contain a multiplier $1 / l_{u}[i]$. Therefore, the criteria (24) and (25) can be considered on each piecewise constant section as the average value of the criteria (27) and (28), respectively, per unit length of the section; criterion (23) based on the modified criterion (26) is similarly considered. If we use the noted interconnection of criteria for determining the values of $S_{1}[i]$ and $S_{2}[i]$, then it is also advisable to normalize these values to assess their proximity to unity. 

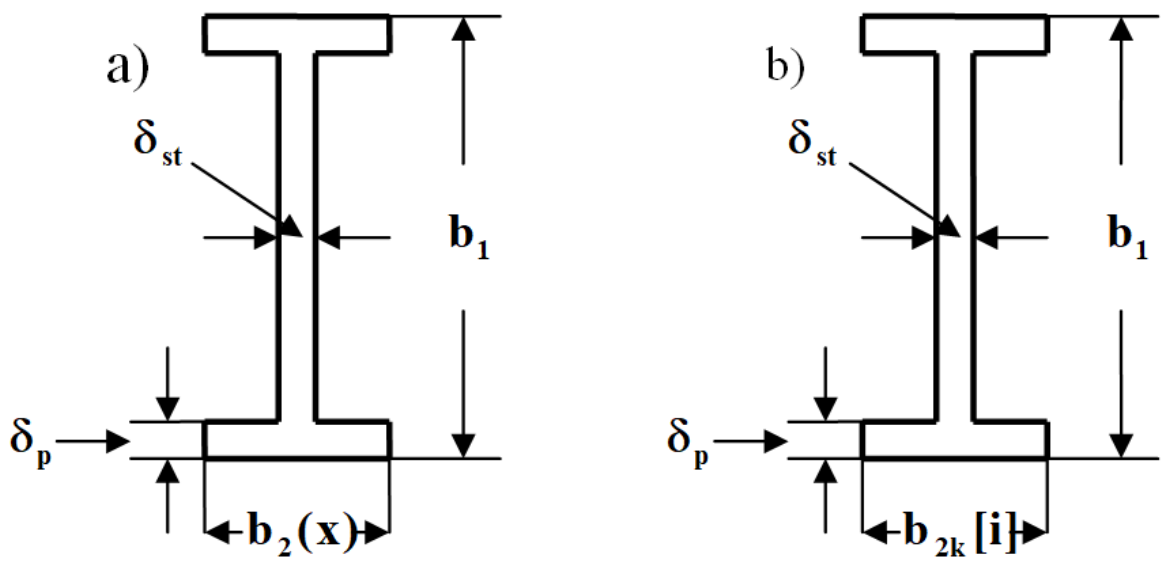

Figure 3. The cross-section of considering rod.

Let us consider criteria similar to those given above for an I-section rod (Figures $3 a, 3 b$ ) with stability constraints or constraints for the value of the first natural frequency when the section height $\left(b_{1}\right)$, shelf thickness $\left(\delta_{p}\right)$, and wall thickness $\left(\delta_{s t}\right)$ do not vary. Only the dimensions of the width of the shelf $\left(b_{2}(x)\right)$ vary with continuous change of dimensions or $b_{2 k}[i]$ $(i=1,2, \ldots, n)$ with piecewise constant change (Figure 2). Natural oscillations occur in one main plane of inertia $x-o-y$ (Figure 2).

A criterion that allows researcher to evaluate the results of solutions of optimization of the width of a shelf under stability constraints or constraints for the value of the first frequency of natural vibrations, for the case when the width of the shelf varies continuously along the length of the rod, was formulated in [6].

This criterion can be presented in the form of three versions:

$$
\begin{aligned}
& \sigma_{1 \omega}^{2}(x)^{*} b_{1}-\sigma_{1 \omega t}^{2}(x) *\left(b_{1}-2 * \delta_{p}\right)- \\
& -3 * E *\left(\omega_{0} * k_{\omega}\right)^{2} * \rho * 2 * \delta_{p} * v_{\omega}^{2}=\text { const } \\
& \sigma_{1 \omega}^{2}(x) * \frac{b_{1}}{2 * \delta_{p}}-\sigma_{1 \omega t}^{2}(x) *\left(\frac{b_{1}}{2 * \delta_{p}}-1\right)- \\
& \quad-3 * E *\left(\omega_{0} * k_{\omega}\right)^{2} * v_{\omega}^{2} * \rho=\text { const } \\
& \bar{\sigma}_{1 \omega t}(x)= \\
& =\sqrt{\sigma_{1 \omega}^{2}(x)^{*} \frac{b_{1}}{2 * \delta_{p}}-\sigma_{1 \omega t}^{2}(x) *\left(\frac{b_{1}}{2 * \delta_{p}}-1\right)-} \\
& \frac{-3 * E *\left(\omega_{0} * k_{\omega}\right)^{2} * v_{\omega}^{2} * \rho}{-3 o n s t,}
\end{aligned}
$$

where $\sigma_{1 \omega}(x)$ and $\sigma_{1 \omega t}$ are respectively, normal stresses in the extreme fibers of the I-section and in the fibers at the boundary of the wall and the shelf.

Version (34) was introduced only to emphasize its relationship with the previously formulated criteria. The use of this version of the criteria with constraints for the value of the lowest frequency of natural oscillations for assessments of the process at the initial stages of optimization can lead to negative values of the radical expressions. Therefore, version (34) should not be used in order to avoid malfunctions of the computational process.

Let us formulate a criterion similar to (32) for piecewise-constant changes in the dimensions of the width of the shelf.

The objective function has the form

$$
V_{0}=\sum_{1}^{n} F[i] * l_{u}[i]
$$

where

$$
F[i]=2 * b_{2} k[i] * \delta_{p}+b_{1} * \delta_{s t}-2 * \delta_{p} * \delta_{s t} .
$$

But since only the values $b_{2 k}[i]$ vary we have

$$
V_{0}=\sum_{1}^{n} 2 * b_{2 k}[i] * \delta_{p} * l_{u}[i]
$$


Assessment Criteria of Optimal Solutions for Creation of Rods With Piecewise Constant Cross-Sections With Stability Constraints or Constraints for Value of the First Natural Frequency. Part 1: Theoretical Foundations

Constraints for the value of the lowest frequency of natural oscillations have the form

$$
\omega_{0} \leq \omega 1[1]
$$

Method of searching for a conditional extremum is used in order to identify the criterion of minimum of the objective function with allowance for constraints for the value of the lowest frequency of natural oscillations.

Let us form an integral, the extremum conditions of which should provide minimum of the objective function (37) and the fulfillment of the conditions that the given frequency will be the lowest frequency of natural oscillation in the principal plane of inertia, i.e.

$$
\omega_{0}=\omega 1[1]
$$

If (39) is satisfied in the form of equality, we have the following condition

$$
\begin{aligned}
\ni_{\omega 1} & =\frac{1}{2} \sum_{i=1}^{n} \int_{x[i-1]}^{x[i]}\left\{E I_{1}[i] *\left(v_{\omega}^{\prime \prime}\right)^{2}-P[i] *\left(v_{\omega}^{\prime}\right)^{2}-\right. \\
& -(\omega 1[1])^{2} *\left[m(x)+\rho^{*} F[i] * v_{\omega}^{2}\right\} d x=0 .
\end{aligned}
$$

The moment of inertia of the section is defined by formula

$$
\begin{aligned}
I_{1}[i] & =\frac{b_{2 k}[i]}{12} *\left[b_{1}^{3}-\left(b_{1}-2 * \delta_{p}\right)^{3}\right]+ \\
& +\frac{\delta_{s t}}{12} *\left(b_{1}-2 * \delta_{p}\right)^{3} .
\end{aligned}
$$

An expression whose extremum provides a minimum of function (37) and the fulfillment of conditions (5) can be written as

$$
\begin{aligned}
V_{0 \omega} & =\sum_{i=1}^{n} 2 * b_{2 k}[i] * \delta_{p} * l_{u}[i]- \\
& -\sum_{i=1}^{n} \int_{x[i-1]}^{x[i]} \lambda_{\omega 1} *\left\{E ^ { * } \left[\frac{b_{2 k}[i]}{12} *\right.\right. \\
& *\left(b_{1}^{3}-\left(b_{1}-2 * \delta_{p}\right)^{3}\right)+\frac{\delta_{s t}}{12} * \\
& \left.*\left(b_{1}-2 * \delta_{p}\right)^{3}\right]^{*}\left(v_{\omega}^{\prime \prime}\right)^{2}-P[1] *\left(v_{\omega}^{\prime}\right)^{2}- \\
& -\left(\omega_{0}\right)^{2} *\left[m(x)+\rho^{*}\left(2 * b_{2 k}[i] * \delta_{p}+\right.\right. \\
& \left.\left.\left.\left.+b_{1} * \delta_{s t}-2 * \delta_{p} * \delta_{s t}\right)\right]^{*} v_{\omega}^{2}\right]\right\} d x .
\end{aligned}
$$

Obviously, the variation of expression (42) by $\lambda_{\omega 1}$ will lead to the fulfillment of condition (5).

Let us write the following system of equations in order to find the minimum of expression (42) under the given conditions (39), (5):

$$
\frac{\partial V_{0 \omega}}{\partial b_{1 k}[i]}=0, \quad i=1,2, . ., n .
$$

We can write the $i$-th equation

$$
\begin{aligned}
& \frac{\partial V_{0 \omega}}{\partial b_{1 k}[i]}=2 * \delta_{p} * l_{u}[i]- \\
& \quad-\int_{x[i-1]}^{x[i]}\left\{\lambda _ { \omega 1 } * \left\{\frac{E}{12} *\left[b_{1}^{3}-\left(b_{1}-2 * \delta_{p}\right)^{3}\right]^{*}\right.\right. \\
& \left.\left.\quad *\left(v_{\omega}^{\prime \prime}\right)^{2}-\left(\omega_{0}\right)^{2} * \rho * 2 * \delta_{p} * v_{\omega}^{2}\right\}\right\} d x=0
\end{aligned}
$$

or

$$
\begin{array}{r}
\int_{x[i-1]}^{x[i]}\left\{\frac{E}{12} *\left[b_{1}^{3}-\left(b_{1}-2 * \delta_{p}\right)^{3}\right] *\left(v_{\omega}^{\prime \prime}\right)^{2}-\right. \\
\left.\left.-\left(\omega_{0}\right)^{2} * \rho^{*} 2 * \delta_{p} * v_{\omega}^{2}\right\}\right\} d x= \\
=2 * \delta_{p} * l_{u}[i] / \lambda_{\omega 1} .
\end{array}
$$

Taking into account that $\delta_{p}$ and $\lambda_{\omega 1}$ are constant values, we can write

$$
\begin{array}{r}
\frac{1}{l_{k}[i]} * \int_{x[i-1]}^{x[i]}\left\{\frac{E}{12} *\left[b_{1}^{3}-\left(b_{1}-2 * \delta_{p}\right)^{3}\right]^{*}\left(v_{\omega}^{\prime \prime}\right)^{2}-\right. \\
\left.\left.-\left(\omega_{0}\right)^{2} * \rho * 2 * \delta_{p} * v_{\omega}^{2}\right\}\right\} d x=\text { const. }
\end{array}
$$


As is known, normal stresses in a rod during bending in a fiber that is separated from the neutral layer by a distance $y_{s}$ are determined by the dependence $\sigma=\left(M * y_{s}\right) / I$.

Since $M=-E I * v^{\prime \prime}$, we have $\sigma=-E^{*} y_{s}^{*} v^{\prime \prime}$. After simple transformations (46) can be rewritten in the form

$$
\begin{aligned}
& \frac{1}{l_{k}[i]} * \int_{x[i-1]}^{x[i]}\left\{\frac { 1 } { 3 * E } * \left[\left(\frac{E * b_{1} * v_{\omega}^{\prime \prime}}{2}\right)^{2} * b_{1}-\right.\right. \\
& \left.-\left(\frac{b_{1}-2 * \delta_{P}}{2} * E * v_{\omega}^{\prime \prime}\right)^{2} *\left(b_{1}-2 * \delta_{p}\right)\right]- \\
& \left.-\left(\omega_{0}\right)^{2} * \rho * 2 * \delta_{p} * v_{\omega}^{2}\right\} d x=\text { const. }
\end{aligned}
$$

Let us note that

$$
\begin{gathered}
\left(\frac{E^{*} b_{1} * v_{\omega}^{\prime \prime}}{2}\right)^{2}=\sigma_{1 \omega}^{2}(x) \\
\left(\frac{b_{1}-2 * \delta_{P}}{2} * E^{*} v_{\omega}^{\prime \prime}\right)^{2}=\sigma_{1 \omega t}^{2}(x)
\end{gathered}
$$

are the square of the normal stress in the extreme fibers of the I-section and in the fibers at the boundary of the wall and the shelf. Thus, (37) can be written as

$$
\begin{gathered}
\frac{1}{l_{k}[i]} * \int_{x[i-1]}^{x[i]}\left[\sigma_{1 \omega}^{2}(x) * b_{1}-\sigma_{1 \omega t}^{2}(x) *\left(b_{1}-2 * \delta_{p}\right)-\right. \\
\left.-3 * E^{*}\left(\omega_{0}\right)^{2} * \rho^{*} 2 * \delta_{p} * v_{\omega}^{2}\right] d x=\text { const }
\end{gathered}
$$

or

$$
\begin{aligned}
& \frac{1}{l_{k}[i]} * \int_{x[i-1]}^{x[i]}\left[\sigma_{1 \omega}^{2}(x) * \frac{b_{1}}{2 * \delta_{p}}-\right. \\
& -\sigma_{1 \omega t}^{2}(x) *\left(\frac{b_{1}}{2 * \delta_{p}}-1\right)- \\
& \left.-3 * E^{*}\left(\omega_{0}\right)^{2} * v_{\omega}^{2}(x) * \rho\right] d x=\text { const. }
\end{aligned}
$$

We can rewrite dependencies (48) and (49) in the form

$$
\begin{aligned}
& S_{1}[i]=\frac{1}{l_{k}[i]} * \int_{x[i-1]}^{x[i]}\left[\sigma_{1 \omega}^{2}(x) * b_{1}-\right. \\
& -\sigma_{1 \omega t}^{2}(x) *\left(b_{1}-2 * \delta_{p}\right)- \\
& \left.-3 * E *\left(\omega_{0}\right)^{2} * \rho^{*} 2 * \delta_{p} * v_{\omega}^{2}\right] d x=\text { const. } \\
& S_{1}[i]=\frac{1}{l_{k}[i]} * \int_{x[i-1]}^{x[i]}\left[\sigma_{1 \omega}^{2}(x) * \frac{b_{1}}{2 * \delta_{p}}-\right. \\
& -\sigma_{1 \omega t}^{2}(x) *\left(\frac{b_{1}}{2 * \delta_{p}}-1\right)- \\
& \left.-3 * E *\left(\omega_{0}\right)^{2} * v_{\omega}^{2}(x) * \rho\right] d x=\text { const. }
\end{aligned}
$$

As noted above, the formulated criteria can be used when only a stability constraint is introduced. In this case, in the criteria expressions, the value of the natural frequency is assumed to be zero.

A comparison of the criteria (50), (51) obtained with a piecewise constant change in the width of the shelf with similar criteria for its continuous change (32), (33) and (34) shows that under the integrals in (50) and (51) are respectively the expressions (32) and (33). Criteria $S_{1}[i]$ and $S_{2}[i]$ contain a multiplier $1 / l_{u}[i]$. Therefore, criteria (50) and (51) can be considered on each piecewise constant section as the average value of criteria (32) and (33), respectively, per unit length of the section.

When optimizing rods with a rectangular and two-T-shaped cross-section under stability constraints or constraints for the value of the first frequency of natural vibrations, if the crosssections continuously vary along its length, criteria were formulated to evaluate the proximity of the obtained solutions to the minimum material-intensive [6]. However, in most cases such projects are not directly implemented. At the same time, they allow researcher to evaluate a real design solution by the criterion of its proximity to the limit (for example, by material consumption), and also be used as a guideline in practical (real) design. One of the options for moving from a limiting project to a really acceptable one is to replace continuous change in cross-sectional dimensions with piecewise constant sections. The boundaries of the plots can 
be selected on the basis of an ideal object, and the dimensions of the cross sections are determined by one of the optimization methods.

Generally this paper proposes criteria that allow researcher to evaluate (reliably) the end of the process of such optimization.

\section{REFERENCES}

1. Lagrange J.-L. Sur la figure des collonnes. // Mescellanea Taurinensia, 1770-1773, Volume 5, pp. 123.

2. Clausen T. Uber die form architektonischer Säulen. // Bull. cl. physico-raath. Acad. St.Petersburg, 1851, Volume 9, pp. 371-380.

3. Nikolai E.L. Zadacha Lagranzha o naivygodneishem ochertanii kolonny [The Lagrange problem of the best shape of the column]. // Bulletin of the St. Petersburg Polytechnic Institute, 1907, No. 8 (in Russian).

4. Lyakhovich L.S., Akimov P.A., Tukhfatullin B.A. O zadachakh poiska minimuma i maksimuma $\mathrm{v}$ stroitel'noi mekhanike [About hill-climbing problems in structural mechanics]. // International Journal for Computational Civil and Structural Engineering, 2017, Volume 13, Issue 2, pp. 103-124 (in Russian).

5. Lyakhovich L.S., Malinovsky A.P., Tukhfatullin B.A. Criteria for Optimal Strengthening of Bar Flange with I-type Cross-section with Stability Constraints on the Value of the First Natural Frequency. // Procedia Engineering, 2016. Volume 153, pp. 427-433.

6. Lyakhovich L.S. Osobye svoistva optimal'nykh sistem i osnovnye napravleniya ikh realizatsii $\mathrm{v}$ metodakh rascheta sooruzhenii [The special properties of optimal systems and the main directions of their implementation in the methods of calculation of structures]. Tomsk, Tomsk State University of Architecture and Building, 2009, 372 pages (in Russian).
7. Lyakhovich L.S., Perelmuter A.V. Nekotorye voprosy optimal'nogo proektirovaniya stroitel'nykh konstruktsii [Some problems of building constructions optimal projecting]. // International Journal for Computational Civil and Structural Engineering, 2014, Volume 10, Issue 2, pp. 1423 (in Russian).

8. Aslami M., Akimov P.A. Analytical solution for beams with multipoint boundary conditions on two-parameter elastic foundations. // Archives of Civil and Mechanical Engineering, 2016, Volume 16, Issue 4, pp. 668-677.

9. Ludeker J.K., Kriegesmann B. Fail-safe optimization of beam structures. // Journal of Computational Design and Engineering, 2019, Volume 6, Issue 3, pp. 260-268.

10. Quinteiro G.F. Beam optimization: improving methodology. // Annals of Nuclear Energy, 2004, Volume 31, Issue 4, pp. 399411.

\section{СПИСОК ПУБЛИКАЦИЙ}

1. Lagrange J.-L. Sur la figure des collonnes. // Mescellanea Taurinensia, 1770-1773, Volume 5, pp. 123.

2. Clausen T. Uber die form architektonischer Säulen. // Bull. cl. physico-raath. Acad. St.Petersburg, 1851, Volume 9, pp. 371-380.

3. Николаи Е.Л. Задача Лагранжа о наивыгоднейшем очертании колонны. // Известия Санкт-Петербургского политехнического института. 1907. №8.

4. Ляхович Л.С., Акимов П.А., Тухфатуллин Б.А. О задачах поиска минимума и максимума в строительной механике. // International Journal for Computational Civil and Structural Engineering, 2017, Volume 13, Issue 2, pp. 103-124.

5. Lyakhovich L.S., Malinovsky A.P., Tukhfatullin B.A. Criteria for Optimal Strengthening of Bar Flange with I-type Cross-section with Stability Constraints on the Value of the First Natural Frequency. // 
Procedia Engineering, 2016. Volume 153, pp. 427-433.

6. Ляхович Л.С. Особые свойства оптимальных систем и основные направления их реализации в методах расчета сооружений. - Томск: Издательство Томского государственного архитектурностроительного университета, 2009. - 372 с.

7. Ляхович Л.С., Перельмутер А.В. Некоторые вопросы оптимального проектирования строительных конструкций. // International Journal for Computational Civil and Structural Engineering, 2014, Volume 10, Issue 2, pp. 14-23.

8. Aslami M., Akimov P.A. Analytical solution for beams with multipoint boundary conditions on two-parameter elastic foundations. // Archives of Civil and Mechanical Engineering, 2016, Volume 16, Issue 4, pp. 668-677.

9. Ludeker J.K., Kriegesmann B. Fail-safe optimization of beam structures. // Journal of Computational Design and Engineering, 2019, Volume 6, Issue 3, pp. 260-268.

10. Quinteiro G.F. Beam optimization: improving methodology. // Annals of Nuclear Energy, 2004, Volume 31, Issue 4, pp. 399411.

Ляхович Леонид Семенович, академик Российской академии архитектуры и строительных наук (РА$\mathrm{ACH})$, профессор, доктор технических наук, профессор кафедры строительной механики, Томский государственный архитектурно-строительный университет; 634003, Россия, г. Томск, Соляная пл. 2;

E-mail: 1ls@tsuab.ru

Акимов Павел Алексеевич, академик Российской академии архитектуры и строительных наук (РАACH), профессор, доктор технических наук; главный ученый секретарь Российской академии архитектуры и строительных наук; заместитель генерального директора по науке 3АО «Научно-исследовательский центр СтаДиО»; профессор Департамента архитектуры и строительства Российского университета дружбы народов; профессор кафедры строительной механики Томского государственного архитектурно-строительного университета; 107031, г. Москва, ул. Большая Дмитровка, д. 24, стр. 1; тел. +7(495) 625-71-63;

факс+7 (495) 650-27-31; Email: akimov@raasn.ru, pavel.akimov@gmail.com.

Тухфатуллин Борис Ахатович, доцент, кандидат технических наук, доцент кафедры строительной механики, Томский государственный архитектурностроительный университет; 634003, Россия, г. Томск, Соляная пл. 2; e-mail: bat9203@gmail.com.

Leonid S. Lyakhovich, Full Member of the Russian Academy of Architecture and Construction Sciences (RAACS), Professor, Dr.Sc., Head of Department of Structural Mechanics, Tomsk State University of Architecture and Building; 634003, Russia, Tomsk, Solyanaya St., 2; e-mail: 1ls@tsuab.ru

Pavel A. Akimov, Full Member of the Russian Academy of Architecture and Construction Sciences (RAACS), Professor, Dr.Sc.; Executive Scientific Secretary of Russian Academy of Architecture and Construction Sciences; Vice-Director for Science Activities, Scientific Research Center "StaDyO"; Professor of Department of Architecture and Construction, Peoples' Friendship University of Russia; Professor of Department of Structural Mechanics, Tomsk State University of Architecture and Building; 24, Ul. Bolshaya Dmitrovka, 107031, Moscow, Russia; phone +7(495) 625-71-63; fax: +7 (495) 650-27-31;

E-mail: akimov@raasn.ru,pavel.akimov@gmail.com.

Boris A. Tukhfatullin, Associate Professor, Ph.D, Associate Professor of Department of Structural Mechanics, Tomsk State University of Architecture and Building; 634003, Russia, Tomsk, Solyanaya St., 2;

E-mail: bat9203@gmail.com. 